\title{
Seasonal variation in water buffaloes' diet grazing in wet grasslands in Northern Greece
}

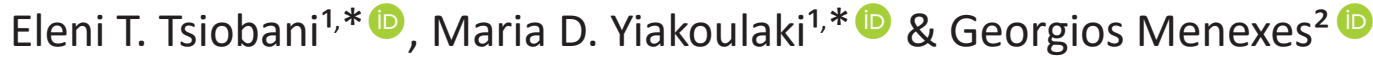

Key words: vegetation composition, dietary preferences, grazing livestock, plant functional types, wetlands.

Ključne besede: vrstna sestava vegetacije, prehranske preference, pašna živina, rastlinski funkcionalni znaki, mokrišča.
Received: 2. 9. 2018

Revision received: 10. 12. 2018

Accepted: 29. 04. 2019

\section{Co-ordinating Editor:}

Salza Palpurina and Orsolya Valkó

\begin{abstract}
Seasonal variability in grasslands' vegetation affects animals' diet selection. We studied the seasonal changes in water buffaloes' diet during grazing in wet grasslands in Northern Greece. We recorded each month the plant species of the vegetation and the species consumed by buffaloes. We categorized the former into three functional groups (graminoids, legumes, and forbs) and the latter into five groups (graminoids, legumes, forbs, shrubs, and trees). There were significant differences in the proportions (\%) of functional groups in the vegetation and in buffaloes' diet between seasons $\left(\chi^{2}\right.$ test, $\left.P<0.05\right)$. Graminoids, legumes, and forbs participated in buffaloes' diet in all seasons, while the less preferred functional groups were trees and shrubs. Buffaloes consumed ten species in all seasons but we observed the most diverse diet, in terms of plant species, in spring. The most frequently consumed species in each functional group were Cynodon dactylon (graminoids), Trifolium repens (legumes), Cichorium intybus (forbs), Rubus sp. (shrubs), and Populus sp. (trees). However, the majority of plant species in buffaloes' diet was in very low proportions $(<1 \%)$, while buffaloes did not sample at all 38 herbaceous species. Researchers need to conduct further research to understand water buffaloes' foraging strategy regarding plants' anti-quality characteristics.
\end{abstract}

\begin{abstract}
Izvleček
Sezonska spremenljivost traviščne vegetacije vpliva na selektivnost prehranjevanja pašnih živali. Proučevali smo sezonske spremembe v prehrani vodnih bivolov med pašo na mokrotnih travnikih v severni Grčiji. Vsak mesec smo beležili vrstno sestavo vegetacije in vrste $s$ katerimi so se bivoli prehranjevali. Združili smo jih v tri funkcionalne skupine (trave, metuljnice in zeli) in nato v pet skupin (trave, metuljnice, zeli, grmovnice in drevesa). Ugotovili smo značilne razlike v deležih (\%) funkcionalnih skupin v vegetaciji in v prehrani bivolov med sezonami $\left(\chi^{2}\right.$ test, $\left.P<0.05\right)$. Trave, metuljnice in zeli so bile prisotne v prehrani bivolov celotno obdobje, manj so izbirali drevesa in grmovnice. Bivoli so se celotno obdobje prehranjevali z desetimi vrstami, najbolj raznoliko prehrano glede vrstne pestrosti smo opazili spomladi. Najbolj pogoste vrste v vsaki od funkcionalnih skupin so bile Cynodon dactylon (trave), Trifolium repens (metuljnice), Cichorium intybus (zeli), Rubus sp. (grmovnice) in Populus sp. (drevesa). Večina rastlinskih vrst v prehrani bivolov je bila zastopana z majhnimi deleži $(<1 \%)$ in bivoli niso izbirali vseh 38 zeliščnih vrst. Nadaljne raziskave so potrebne za razumevanje pašne strategije vodnih bivolov v povezavi z značilnostmi rastlinskih vrst, ki kažejo na njihov slabšo kakovost.
\end{abstract}

1 Department of Range Science (236), Faculty of Agriculture, Forestry and Natural Environment, School of Forestry and Natural Environment, Aristotle University of Thessaloniki, 54124 Thessaloniki, Greece.

2 Department of Field Crops and Ecology, Faculty of Agriculture, Forestry and Natural Environment, Aristotle University of Thessaloniki, 54124 Thessaloniki, Greece.

* Corresponding authors: The two authors equally contributed to this study. E-mail addresses: elenitsiobani@gmail.com; yiak@for.auth.gr 


\section{Introduction}

Domestic livestock face multiple challenges during their foraging routine as they have to cope with heterogeneous landscapes and diverse environmental conditions (Launchbaugh et al. 2006, Ginane et al. 2015). The choice of their diet could be considered a strategy to obtain maximum quantity and sufficient quality of forage (Mládek et al. 2013). Therefore, the plant species that the animals included in their diet are the result of a careful decision in order to meet their physiological demands (Owen-Smith \& Novellie 1982, Soder et al. 2009).

The Greek water buffalo is an endangered local breed of the Eurasian water buffalo (Bubalus bubalis) (FAO 2007, Tsiobani et al. 2016), which has been extensively raised in the wetlands of the country since the end of the $19^{\text {th }}$ century (Georgoudis 1993). Water buffaloes, like cattle, are characterized as bulk grazers, meaning that they are less selective in order to fill their stomachs (Whitmore 2000). However, due to the large volume, the slow movement, and the high bacterial activity of their rumen, they have a different diet than cattle and sheep (Napolitano et al. 2013, Jerrentrup et al. 2015, Tóth et al. 2018). Although there are numerous studies in the literature about the diet selection of cattle and other domestic animals (Cibils et al. 2004, Fraser et al. 2009, Soder et al. 2009, Ginane \& Dumont 2010), data concerning the water buffaloes' dietary behaviour is very limited (Napolitano et al. 2007, Antkowiak et al. 2012, Tsiobani et al. 2014). This knowledge is significant for the protection of this local breed as well as for the achievement of proper management of wet grasslands' biodiversity because the selective grazing affects the structure and the dynamics of plant communities (Duncan et al. 2006).

Wet grasslands constitute a particular category of grasslands (Papanastasis \& Ispikoudis 2012) and a type of wetlands. They are either found on the shorelines of lakes or along floodplains of rivers, wherein they are temporarily flooded or saturated with water. This periodic flooding allows the growth of plants typical on moist soils (Keddy 2010). Wet grasslands, in general, have unique ecological characteristics, that resemble both terrestrial and aquatic ecosystems, providing a natural habitat for several plant and animal species (van der Valk 2006, Verhoeven et al. 2006). According to Kazoglou (2007), the vegetation of the wet grasslands in Northern Greece is mainly herbaceous, including plant species from the genera Agrostis, Alopecurus, Carex, Cyperus, Festuca, Juncus, Poa, and Scirpus, that belong to graminoids, Trifolium and Vicia from legumes, and Althaea, Cirsium, Eleocharis, Galium, Lysimachia, Mentha, Myosotis, Potentilla, Ranunculus, Rorippa, Rumex, and Veronica from forbs.
Throughout their life history, plant species are either dormant or under growth (Moen et al. 2006). This means that there is seasonality in their abundance in the grassland as well as variety in their phenological stage and nutritive value (Villalba \& Provenza 2009). This seasonal cycle of forage availability and quality directly affects grazing animals' diet composition (Hejcman et al. 2008) and imposes constraints on animals (Zweifel-Schielly et al. 2012). Plant species in grasslands according to their response to environmental factors are classified into functional groups such as graminoids (including grasses, sedges, and rushes), legumes, forbs, shrubs, and trees (Blondel 2003). Since environmental conditions change between seasons, the ratio of different plant functional groups in wet grasslands also differs between seasons (Keddy 2010), affecting thus the water buffaloes' diet. Therefore, the proportion of different plant functional groups in the buffalos' diet is not expected to coincide with their proportion in the wet grasslands' vegetation as stated by other researchers (Galt et al. 1982, Hejcman et al. 2008) for different kind of grazing animals and grasslands vegetation. In this context, the aim of this study was to investigate the seasonal changes of different plant functional groups in the diet of Greek water buffaloes during grazing in wet grasslands in Northern Greece.

\section{Material and methods}

\subsection{Study area and animal facilities}

The study was conducted in the wet grasslands of Chrysochorafa (longitude 23ำ'08.48" E, latitude $41^{\circ} 10^{\prime} 46.67^{\prime \prime} \mathrm{N}$ ), a rural village in Northern Greece, from May 2015 to April 2016. The grasslands cover an area of 91.19 ha and are located on the shores of Lake Kerkini, which is an artificial freshwater lake created at the site of a former natural swamp. The lake is characterized by large fluctuations of water level, where the minimum levels are observed between September and February and the maximum levels are observed between early May and early June (Papastergiadou \& Balabonas 1992). The wider area of the Lake Kerkini is under protection according to the Ramsar Convention.

The climate of the region is intermediate between Mediterranean and Mid-European, characterized by hot, dry summers and cold, wet winters. The seasonal yearly mean air temperature during the study period ranged from $4.6^{\circ} \mathrm{C}$ in the winter and $25.4^{\circ} \mathrm{C}$ in the summer. Also, the seasonal yearly mean precipitation ranged from $24.4 \mathrm{~mm}$ during summer to $72.3 \mathrm{~mm}$ during autumn (Weather Station of Chrysochorafa 2018). Autumn was the wettest season with normal expected temperature levels, while summer was the driest season of all. 

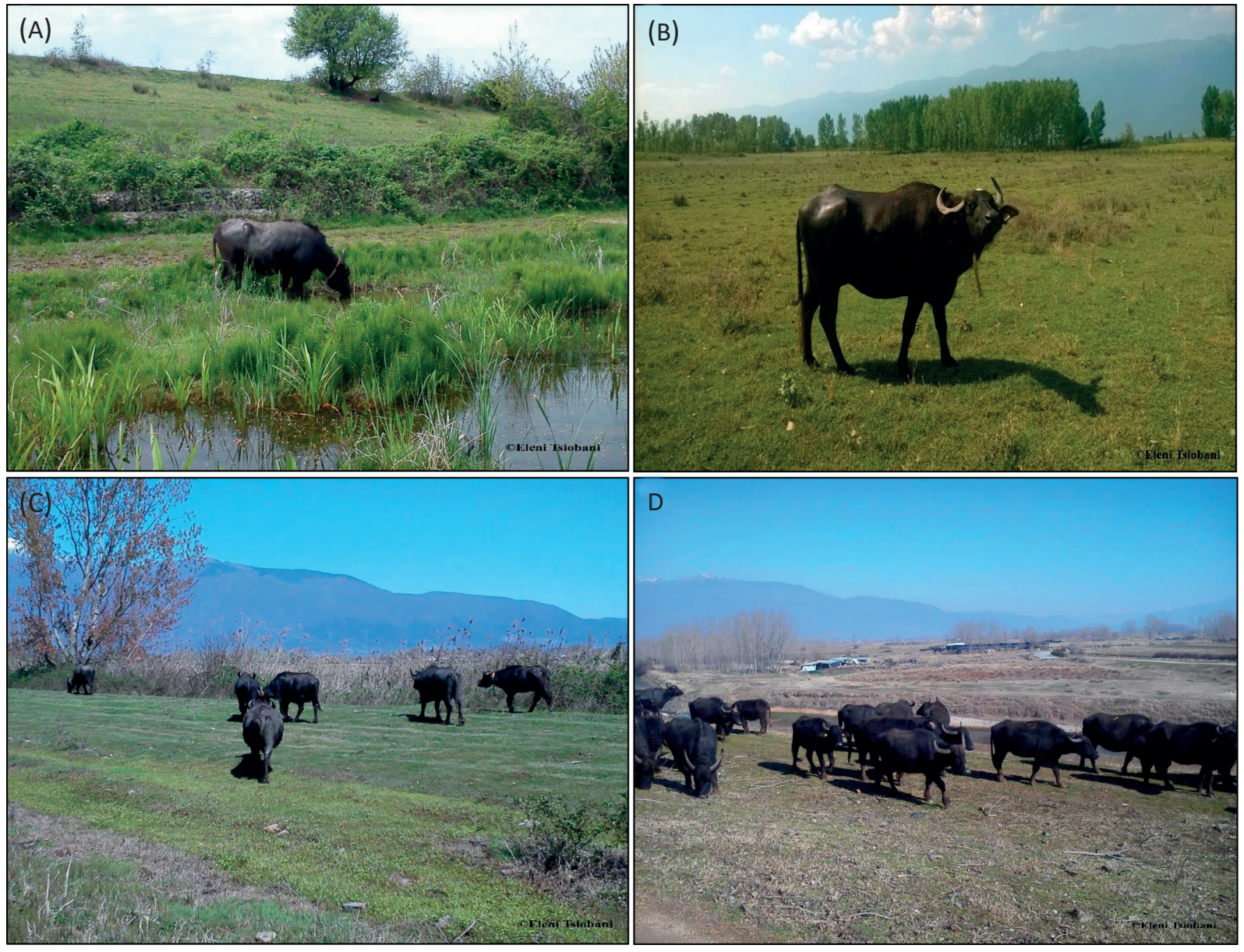

Figure 1: Greek water buffaloes grazing on the wet grasslands of the Lake Kerkini in Northern Greece during (A) spring, (B) summer, (C) autumn, (D) winter. Photos provided by Eleni Tsiobani.

Slika 1: Grški vodni bivoli na paši na mokrotnih travnikih ob jezeru Kerkini v severni Grčiji: (A) spomladi, (B) poleti, (C) jeseni, (D) pozimi. Fotografije Eleni Tsiobani.

The soils are alluvial, supporting vegetation of great variety (Psilovikos \& Margoni 2010), mainly herbaceous species. According to our observations, woody species (shrubs and trees) were present but scattered at the edges of the study area. Clematis vitalba, Cornus sanguineus, Cytisus monspessulanus, Genista tinctoria (an endemic species of the Balkan Peninsula), Paliurus spina-christi, Rubus sp., and Sambucus nigra were the present shrub species, while Acacia sp., Fagus sp., Morus sp., Olea europaea, Platanus sp., Populus sp., and Salix alba were the trees. Phragmites australis, Typha latifolia, and Scirpus sylvaticus were present in the marshes of the irrigation ditches in the study area. The areas adjacent to the wet grasslands were cultivated by extended crop cultures, principally maize and wheat.

A herd of 91 Greek water buffaloes was selected for the purposes of the study. The animals grazed on the wet grasslands every day (Figure 1) and returned to the stable in the late afternoon. The buffaloes also grazed while wal- lowing into the canals as well as in the several mudholes present in the area. The herd was constantly supervised by two herders in order to guide the animals to areas of better forage quantity and quality according to the season, and also to prevent them from entering cultivated fields. Supplementary feedstuff was not given to the animals for three days prior and during the observation days.

\subsection{Data collection}

The composition (\%) of herbaceous species of the wet grasslands was determined on transects with the line intercept method (Bonham 2013). Every month, prior to the observations of the animals, we placed three nonpermanent $25 \mathrm{~m}$ long line transects in relatively homogeneous areas that were representative of the wet grasslands' vegetation type. Along each line, we dropped vertically a single pin every $0.25 \mathrm{~m}$ and we recorded all species the 
pin hit (each species was counted only once per pin-drop, even in the cases where the pin hit several parts or more individuals of the species). The total number of hits was 100 per transect, and 900 per season (see Table 1, the columns regarding vegetation). The recorded herbaceous species were identified and categorized into three functional groups (graminoids, legumes, and forbs). The proportion of each plant species was calculated as the number of hits a plant received per transect divided by 100 . The monthly proportion (\%) of each species was the average of the three transects. Thus, the seasonal proportion (\%) of each species was the average of their three monthly proportions. The same procedure was followed for the calculation of the seasonal proportions (\%) of plant functional groups. It should be mentioned here that it was not feasible to measure Phragmites australis, Scirpus sylvaticus, and Typha latifolia in the canals, as they were covered by water throughout the year. Thus, although these species were consumed by the buffaloes and contributed to their diet, they were not included in the plant species composition of the wet grasslands' vegetation.

The focal sampling technique (Altmann 1974) was applied to the whole group in order to determine water buffaloes' diet selection. All the animals had numbered collars around their neck so that they could be easily identified from a distance. The observations were carried out over a period of twelve consecutive months, for two consecutive days per month and for five hours per observation day. Each hour was divided into two half-hour observation periods. Two well-trained observers conducted the observations. The observers had already spent several days within the herd prior to the observations so that the animals would get acquainted to them and not be disturbed by their presence. The first observer, with the help of a synchronized chronometer, constantly followed the herd, observing each animal for 18 seconds. If the observed animal was grazing, the observer recorded in protocol sheets the consumed plant species. The second observer collected in separate paper bags representative samples of the consumed plant species for identification. We had 240 observation periods for the whole study ( 2 observation periods per hour $\times 5$ hours per observation day $\times 2$ days per month $\times 12$ months). These 240 observation periods corresponded to 11416 recorded animal observations regarding their diet $(\mathrm{N}=3930$ in spring, $\mathrm{N}=3866$ in summer, $\mathrm{N}=2083$ in autumn, and $\mathrm{N}=1537$ in winter: see Table 1 at the columns relevant to water buffaloes' diet). The different number of animal observations per season is due to the fact that in each observation period not all animals grazed. They might perform other activities, such as moving, standing, ruminating, wallowing, lying, or drinking water. The collected plants species were identified and cat- egorized into five functional groups, e.g. graminoids, legumes, forbs, shrubs, and trees. We calculated the monthly proportion (\%) of each plant species in the buffaloes' diet and we determined the seasonal proportion (\%) as the average of the three monthly values. We followed the same procedure for the calculation of the seasonal proportions (\%) of plant functional groups in the diet. All plant species were identified with the use of the Treatises Mountain Flora of Greece (Strid 1986, Strid \& Tan 1991) and Flora Europaea (Tutin et al. 1964-1980).

\subsection{Statistical analysis}

The chi-square $\left(\chi^{2}\right)$ test was applied to compare the distribution of proportions (\%) of the plant functional groups in the wet grassland's vegetation across seasons. Specific comparisons for their proportions (\%) were performed with the z-test at significance level $P<0.05$. Chi-square $\left(\chi^{2}\right)$ was also applied for the proportions (\%) of the plant functional groups in water buffaloes' diet. Additionally, the Spearman rank correlation was used to examine whether the proportions (\%) of different plant functional groups in buffaloes' diet are related with their proportions (\%) in the wet grasslands' vegetation. A species-wise Spearman rank correlation was also performed for each season. The significance level was set at $P<0.05$. All statistical analyses were performed with SPSS v.25 software (SPSS Inc., Ill: Chicago, USA).

\section{Results}

\subsection{Plant species composition of the wet grasslands' vegetation}

The chi-squared test showed that there was a statistically significant relationship between plant functional groups of the wet grasslands' vegetation and seasons $\left(\chi^{2}=251.297, \mathrm{df}=6, P<0.001\right)$ (Table 1). The seasonal proportion (\%) of graminoids in the grasslands' vegetation was at significantly higher levels during summer and autumn compared to the two other seasons. On the contrary, forbs had their lowest values $(P<0.001)$ during that time. The proportion (\%) of legumes during summer was significantly higher than the other seasons $(P<0.001)$. Alopecurus pratensis, Carex sp., Cynodon dactylon, Hordeum murinum, Trifolium repens, Anagallis arvensis, Cichorium intybus, Fumaria officinalis, and Plantago lanceolata were the present plant species in the grassland throughout the year. Cynodon dactylon was the most dominant species from the graminoids, Trifolium repens from the legumes and Cichorium intybus from the forbs (Table 2). 
Table 1: Seasonal proportions (\%) of plant functional groups in the vegetation (graminoids, legumes, and forbs) and in the diet (graminoids, legumes, forbs, shrubs, and trees) of water buffaloes grazing in the wet grasslands of the Lake Kerkini, Northern Greece. Comparisons of distributions of their proportions (\%) were performed with the chi-square test at $P<0.05$. Specific comparisons for their proportions (\%) were performed with the z-test.

Tabela 1: Sezonski deleži (\%) rastlinskih funkcionalnih skupin v vegetaciji (trave, metuljnice in zeli) in v prehrani vodnih bivolov (trave, metuljnice, zeli, grmovnice in drevesa), ki se pasejo na mokrotnih travnikih ob jezeru Kerkini (Severna Grčija). Primerjave porazdelitev deležev $(\%)$ smo testirali z hi-kvadrat testom $(P<0,05)$. Posebne primerjave njihovih deležev $(\%)$ smo naredili z z-testom.

\begin{tabular}{|c|c|c|c|c|c|c|c|c|}
\hline \multirow{3}{*}{$\begin{array}{l}\text { Plant } \\
\text { functional } \\
\text { group }\end{array}$} & \multicolumn{8}{|c|}{ Season } \\
\hline & \multicolumn{2}{|c|}{ Spring } & \multicolumn{2}{|c|}{ Summer } & \multicolumn{2}{|c|}{ Autumn } & \multicolumn{2}{|c|}{ Winter } \\
\hline & $\begin{array}{l}\text { Vegetation } \\
(\mathrm{n}=900)^{1} \\
\end{array}$ & $\begin{array}{l}\text { Water buffaloes } \\
\operatorname{diet}(\mathrm{N}=3930)^{2}\end{array}$ & $\begin{array}{c}\text { Vegetation } \\
(\mathrm{n}=900) \\
\end{array}$ & $\begin{array}{l}\text { Water buffaloes } \\
\text { diet }(N=3866) \\
\end{array}$ & $\begin{array}{l}\text { Vegetation } \\
(\mathrm{n}=900) \\
\end{array}$ & $\begin{array}{l}\text { Water buffaloes } \\
\text { diet }(N=2083)\end{array}$ & $\begin{array}{c}\text { Vegetation } \\
(\mathrm{n}=900) \\
\end{array}$ & $\begin{array}{l}\text { Water buffaloes } \\
\text { diet }(\mathrm{N}=1537)\end{array}$ \\
\hline Graminoids & $39.3^{\mathrm{a}}$ & $44.5^{\mathrm{B}}$ & $57.1^{\mathrm{b}}$ & $68.2^{\mathrm{C}}$ & $60.8^{\mathrm{b}}$ & $76.8^{\mathrm{A}}$ & $45.2^{\mathrm{a}}$ & $64.5^{\mathrm{C}}$ \\
\hline Legumes & $25.6^{\mathrm{a}}$ & $22.1^{\mathrm{B}}$ & $32.6^{\mathrm{b}}$ & $23.8^{\mathrm{B}}$ & $25.2^{\mathrm{a}}$ & $9.3^{\mathrm{A}}$ & $23.4^{\mathrm{a}}$ & $16.3^{\mathrm{C}}$ \\
\hline Forbs & $35.1^{\mathrm{a}}$ & $25.7^{\mathrm{B}}$ & $10.3^{\mathrm{b}}$ & $4.6^{\mathrm{C}}$ & $14.0^{\mathrm{b}}$ & $10.5^{\mathrm{A}}$ & $31.3^{\mathrm{a}}$ & $16.0^{\mathrm{D}}$ \\
\hline Shrubs & - & $6.6^{\mathrm{B}}$ & - & $2.1^{\mathrm{A}}$ & - & $2.8^{\mathrm{A}}$ & - & $2.6^{\mathrm{A}}$ \\
\hline Trees & - & $1.0^{\mathrm{A}}$ & - & $1.2^{\mathrm{A}}$ & - & $0.7^{\mathrm{A}}$ & - & $0.6^{\mathrm{A}}$ \\
\hline Total & 100.0 & 100.0 & 100.0 & 100.0 & 100.0 & 100.0 & 100.0 & 100.0 \\
\hline
\end{tabular}

${ }^{1}$ The letter $\mathrm{n}$ in the parentheses indicates the total number of hits per season regarding the wet grasslands' vegetation.

${ }^{2}$ The letter $\mathrm{N}$ in the parentheses is the total number of observations per season regarding the water buffaloes' diet. $\mathrm{N}$ is different per season as not all animals grazed during the observation periods.

a,b Superscript lowercase letters denote the significant differences in the proportions (\%) of plant functional groups in wet grasslands' vegetation between seasons at the level $0.05\left(\chi^{2}=251.297, \mathrm{df}=6, P<0.001\right)$.

$\mathrm{A}, \mathrm{B}, \mathrm{C}, \mathrm{D}$ Superscript capital letters denote the significant differences in the proportions (\%) of plant functional groups in water buffaloes' diet between seasons at the level $0.05\left(\chi^{2}=1219.255, \mathrm{df}=12, P<0.001\right)$.

Table 2: Seasonal proportion (\%) of plant species in the wet grasslands vegetation of the Lake Kerkini, Northern Greece and their proportions (\%) in the diet of water buffaloes. The bold format, both in vegetation and buffaloes diet, indicates values beyond $1 \%$.

Tabela 2: Sezonski deleži (\%) rastlinskih vrst na mokrotnih travnikih ob jezeru Kerkini (severna Grčija) in njihovi deleži (\%) v prehrani vodnih bivolov. Krepko so označene vrednosti nad $1 \% \mathrm{v}$ vegetaciji in v prehrani.

\begin{tabular}{|c|c|c|c|c|c|c|c|c|}
\hline \multirow{3}{*}{$\begin{array}{l}\text { Plant } \\
\text { functional } \\
\text { group }\end{array}$} & \multicolumn{8}{|c|}{ Season } \\
\hline & \multicolumn{2}{|c|}{ Spring } & \multicolumn{2}{|c|}{ Summer } & \multicolumn{2}{|c|}{ Autumn } & \multicolumn{2}{|c|}{ Winter } \\
\hline & Vegetation & $\begin{array}{c}\text { Water } \\
\text { buffaloes' } \\
\text { diet }\end{array}$ & Vegetation & $\begin{array}{c}\text { Water } \\
\text { buffaloes' } \\
\text { diet }\end{array}$ & Vegetation & $\begin{array}{c}\text { Water } \\
\text { buffaloes' } \\
\text { diet }\end{array}$ & Vegetation & $\begin{array}{c}\text { Water } \\
\text { buffaloes' } \\
\text { diet }\end{array}$ \\
\hline \multicolumn{9}{|l|}{ Graminoids } \\
\hline Alopecurus pratensis & 0.2 & 3.1 & 5.1 & 1.7 & 10.3 & 2.3 & 0.1 & 1.5 \\
\hline Bromus erectus & 0.9 & 0.5 & & & & & & \\
\hline Bromus hordeaceus & 2.1 & 0.8 & & & & & & \\
\hline Bromus intermedius & 0.2 & 0.1 & & & & & & \\
\hline Carex sp. & 1.0 & 2.0 & 1.1 & 2.7 & 4.9 & 0.2 & 14.4 & 2.7 \\
\hline Cynodon dactylon & 29.5 & 25.7 & 49.8 & 56.6 & 43.4 & 60.5 & 29.9 & 61.1 \\
\hline Cyperus fuscus & & & & & & 0.1 & & \\
\hline Festuca valesiaca & 0.2 & & & & & & & \\
\hline Hordeum murinum & 3.1 & 2.5 & 0.2 & 2.6 & 0.3 & 0.1 & 0.8 & 0.1 \\
\hline Juncus subulatus & 0.1 & $0.0^{*}$ & 0.1 & 0.1 & & & & \\
\hline Phragmites australis & & 2.0 & & 1.0 & & 5.3 & & 0.3 \\
\hline Poa arvensis & & & 0.1 & & & & & \\
\hline Poa pratensis & 0.6 & & & & & & & \\
\hline Poa trivialis & 0.7 & 3.6 & 0.1 & 0.6 & & & & \\
\hline Scirpus sylvaticus & & 0.1 & & & & & & \\
\hline
\end{tabular}




\begin{tabular}{|c|c|c|c|c|c|c|c|c|}
\hline \multirow{3}{*}{$\begin{array}{l}\text { Plant } \\
\text { functional } \\
\text { group }\end{array}$} & \multicolumn{8}{|c|}{ Season } \\
\hline & \multicolumn{2}{|c|}{ Spring } & \multicolumn{2}{|c|}{ Summer } & \multicolumn{2}{|c|}{ Autumn } & \multicolumn{2}{|c|}{ Winter } \\
\hline & Vegetation & $\begin{array}{c}\text { Water } \\
\text { buffaloes' } \\
\text { diet }\end{array}$ & Vegetation & $\begin{array}{c}\text { Water } \\
\text { buffaloes' } \\
\text { diet }\end{array}$ & Vegetation & $\begin{array}{c}\text { Water } \\
\text { buffaloes' } \\
\text { diet }\end{array}$ & Vegetation & $\begin{array}{c}\text { Water } \\
\text { buffaloes' } \\
\text { diet }\end{array}$ \\
\hline Setaria verticillata & & & & & 1.4 & 6.8 & & \\
\hline Sorghum halepense & & & & & 0.2 & 0.2 & & \\
\hline Sorghum scoparium & & & 0.6 & 2.7 & & & & \\
\hline Typha latifolia & & 0.2 & & & & & & \\
\hline Vulpia myuros & 0.8 & 0.5 & & & & & & \\
\hline \multicolumn{9}{|l|}{ Legumes } \\
\hline Melilotus neapolitanus & 0.9 & 0.7 & 0.6 & 0.0 & & & & \\
\hline Trifolium repens & 24.7 & 22.4 & 31.0 & 23.9 & 24.4 & 8.0 & 23.4 & 12.1 \\
\hline Vicia sp. & & & 1.0 & 0.1 & 0.8 & 0.1 & & \\
\hline \multicolumn{9}{|l|}{ Forbs } \\
\hline Ajuga reptans & 0.2 & & & & & & & \\
\hline Anagallis arvensis & 0.8 & & 0.3 & 0.2 & 0.4 & 0.4 & 0.6 & 0.1 \\
\hline Anagallis tenella & 0.2 & 0.4 & & & 0.1 & & & \\
\hline Anthemis arvensis & 0.6 & & & & & & & \\
\hline Apium nodiflorum & & & & & 0.1 & & & \\
\hline Bellis perennis & 0.3 & & & & & & & \\
\hline Berteroa obliqua & 0.4 & & & & & & & \\
\hline Calystegia silvatica & 0.2 & 0.0 & & & & & & \\
\hline Capsella bursa-pastoris & 0.3 & 0.9 & & & & & & \\
\hline Cardamine hirsuta & & & & & & & 0.3 & \\
\hline Carduus nutans & 0.1 & 0.5 & & & & & & \\
\hline Carlina acanthifolia & 1.1 & & & & & & & \\
\hline Carlina vulgaris & 0.3 & 1.3 & 0.1 & 0.0 & 0.1 & 0.0 & & \\
\hline Cerastium arvense & 1.2 & 2.7 & & & & & & \\
\hline Cerastium brachypetalum & 0.2 & & & & & & & \\
\hline Chrysanthemum morifolium & 0.1 & & & & & & & \\
\hline Cichorium intybus & 7.8 & 8.2 & 6.0 & 2.3 & 4.8 & 7.4 & 4.1 & 14.0 \\
\hline Convolvulus arvensis & & & 0.1 & 0.4 & & & & \\
\hline Crepis setosa & 0.7 & & 0.1 & & & & & \\
\hline Daucus muricatus & 0.9 & 0.3 & & & & & & \\
\hline Diplotaxis muralis & & & & & & & 0.1 & \\
\hline Erodium cicutarium & 0.1 & 2.7 & & & 0.8 & & 0.1 & \\
\hline Erodium moschatum & 0.2 & 0.5 & & & & & & \\
\hline Erysimum graecum & & & & & & & 1.7 & \\
\hline Euphorbia helioscopia & 0.2 & & & & & & & \\
\hline Fumaria officinalis & 2.1 & 0.7 & 0.1 & 0.0 & 1.2 & 0.1 & 2.6 & \\
\hline Geranium rotundifolium & 2.7 & & & & & & 11.6 & 0.6 \\
\hline Inula hirta & & & & & 0.9 & & & \\
\hline Knautia orientalis & & & & & & & 0.8 & \\
\hline Leontodon crispus & & & & & & & 0.2 & \\
\hline Leontodon tuberosus & 1.2 & & & & & & & \\
\hline Lepidium latifolium & & & & & & & 1.6 & \\
\hline Malva sylvestris & 0.2 & 0.1 & & & & & & \\
\hline Mentha pulegium & 0.1 & 0.4 & 0.2 & 0.0 & 0.2 & 0.0 & & \\
\hline Myosotis arvensis & 0.1 & 0.4 & & & & & & \\
\hline Nigella damascena & & & 0.1 & 0.0 & & & & \\
\hline Origanum vulgare & & & & & 0.1 & 0.1 & & \\
\hline Oxalis corniculata & & & & & 0.7 & & & \\
\hline
\end{tabular}




\begin{tabular}{|c|c|c|c|c|c|c|c|c|}
\hline \multirow{3}{*}{$\begin{array}{l}\text { Plant } \\
\text { functional } \\
\text { group }\end{array}$} & \multicolumn{8}{|c|}{ Season } \\
\hline & \multicolumn{2}{|c|}{ Spring } & \multicolumn{2}{|c|}{ Summer } & \multicolumn{2}{|c|}{ Autumn } & \multicolumn{2}{|c|}{ Winter } \\
\hline & Vegetation & $\begin{array}{c}\text { Water } \\
\text { buffaloes' } \\
\text { diet }\end{array}$ & Vegetation & $\begin{array}{c}\text { Water } \\
\text { buffaloes' } \\
\text { diet }\end{array}$ & Vegetation & $\begin{array}{c}\text { Water } \\
\text { buffaloes' } \\
\text { diet }\end{array}$ & Vegetation & $\begin{array}{c}\text { Water } \\
\text { buffaloes } \\
\text { diet }\end{array}$ \\
\hline Picris sprengeriana & 0.1 & 0.0 & & & & & & \\
\hline Plantago amplexicaulis & 1.9 & 1.0 & & & & & 1.9 & 0.3 \\
\hline Plantago coronopus & 0.2 & & & & & & & \\
\hline Plantago lanceolata & 4.2 & 4.0 & 0.7 & 0.4 & 1.7 & 0.0 & 1.1 & 0.4 \\
\hline Plantago major & & & & & 0.1 & 1.2 & & \\
\hline Polygonum aviculare & & & & & 0.9 & & & \\
\hline Portulaca oleracea & 0.1 & 0.1 & & & 0.4 & 1.6 & & \\
\hline Potentilla reptans & 0.4 & & 1.4 & & & & 2.0 & \\
\hline Prenanthes purpurea & 0.3 & 0.2 & & & 1.0 & & 0.1 & 0.7 \\
\hline Pulicaria vulgaris & & & & & & & 0.6 & \\
\hline Pulmonaria officinalis & 0.3 & & & & & & & \\
\hline Ranunculus repens & 0.1 & 2.3 & 0.1 & & & & & \\
\hline Ranunculus sardous & 0.3 & & 0.3 & 0.1 & & & & \\
\hline Reichardia picroides & 1.0 & 0.3 & 0.3 & & & & & \\
\hline Reichardia vulgare & & & & & & & 0.4 & \\
\hline Rorippa sylvestris & 0.8 & 0.0 & & & & & 0.1 & \\
\hline Rumex crispus & 0.3 & & 0.1 & 0.0 & & & & \\
\hline Rumex pulcher & & & & & 0.1 & & 0.6 & 2.5 \\
\hline Ruta graveolens & & & 0.1 & 0.7 & & & & \\
\hline Scleranthus perennis & 0.2 & & & & & & & \\
\hline Silybum marianum & & & 0.1 & 0.0 & & & & \\
\hline Sisymbrium altissimum & 0.9 & & & & & & & \\
\hline Stellaria palustris & 0.7 & & & & & & 0.1 & \\
\hline Taraxacum sp. & & & & & & & 0.2 & \\
\hline Tordilium maximum & & & & & 0.1 & & & \\
\hline Verbascum sinuatum & 0.1 & & & & 0.2 & & & \\
\hline Veronica arvensis & 0.2 & & & & & & & \\
\hline Veronica hederifolia & & & & & & & 0.7 & \\
\hline Veronica serpyllifolia & 0.1 & & & & & & & \\
\hline Shrubs & & & & & & & & \\
\hline Clematis vitalba & & 0.9 & & 0.1 & & & & \\
\hline Cornus sanguineus & & 0.6 & & & & & & \\
\hline Cytisus monspessulanus & & 0.4 & & & & & & \\
\hline Genista tinctoria & & 0.3 & & & & & & \\
\hline Paliurus spina-christi & & 0.1 & & & & & & \\
\hline Rubus sp. & & 5.6 & & 2.5 & & 1.3 & & 2.8 \\
\hline Sambucus nigra & & & & & & 3.8 & & \\
\hline Trees & & & & & & & & \\
\hline Acacia sp. & & 0.1 & & & & 0.1 & & \\
\hline Fagus sp. & & 0.0 & & & & & & \\
\hline Morus sp. & & 0.1 & & & & & & \\
\hline Olea europaea & & & & 0.1 & & & & \\
\hline Platanus sp. & & 0.0 & & & & & & \\
\hline Populus sp. & & 0.4 & & 1.1 & & 0.4 & & 0.7 \\
\hline Salix alba & & 0.2 & & 0.0 & & 0.1 & & \\
\hline Total & 100.0 & 100.0 & 100.0 & 100.0 & 100.0 & 100.0 & 100.0 & 100.0 \\
\hline
\end{tabular}

* The value 0.0 in water buffaloes' diet corresponds to plant species with proportions (\%) less than 0.05 . 


\subsection{Plant species composition of the water bufalloes' diet}

According to the chi-square test, a statistically significant relationship was detected between plant functional groups of the water buffaloes' diet and seasons $\left(\chi^{2}=1219.255, \mathrm{df}=12, P<0.001\right)($ Table 1$)$. The herbaceous vegetation (graminoids, legumes, and forbs) was the main component of the water buffaloes' diet for all four seasons, as it constituted $92.3 \%$ (spring), $96.6 \%$ (summer and autumn), and $96.8 \%$ (winter) of the buffaloes' diet. On the other hand, the woody species (shrubs and trees) were less consumed (from 3.2\% in winter to $7.6 \%$ in spring). Alterations in the composition of the water buffaloes' diet were observed in all seasons, with graminoids remaining predominant. However, they had a lower contribution during spring, due to the increased participation of legumes, forbs, and shrubs $(P<0.001)$. Legumes had their lowest value during autumn $(P<0.001)$, while trees were constantly a negligible component of animals' diet throughout the year.

A total of 66 plant species (16 graminoids, 3 legumes, 33 forbs, 7 shrubs, and 7 trees) were included in the water buffaloes' diet (Table 2). The animals consumed a broader variety of plant species in spring (49 species) compared to summer (28), autumn (23), and winter (15). The same trend had also appeared for the plant functional groups. Specifically, 13 graminoids were recorded in spring, eight in summer, seven in autumn, and five in winter. Five graminoids (Alopecurus pratensis, Carex sp., Cynodon dactylon, Hordeum murinum, and Phragmites australis) were present in water buffaloes' diet during all four seasons. From these species, Cynodon dactylon was the dominant graminoid in the diet, ranging from $25.7 \%$ in spring to $61.1 \%$ in winter, while the rest ones were observed in much lower proportions. Specifically, Alopecurus pratensis contributed to the diet from $1.5 \%$ in winter to $3.1 \%$ in spring, Carex sp. from $0.2 \%$ in autumn to $2.7 \%$ in winter and summer, Hordeum murinum from $0.1 \%$ in autumn and winter to $2.6 \%$ in summer, and Phragmites australis from $0.3 \%$ in winter to $5.3 \%$ in autumn (Table 2). Regarding the contribution of other graminoids to the buffaloes' diet within seasons, it was noted that Bromus erectus, Bromus hordeaceus, Bromus intermedius, Juncus subulatus, Poa trivialis, Scirpus sylvaticus, Typha latifolia, and Vulpia myuros were also present during spring apart from the constantly consumed species. Also, Juncus subulatus, Poa trivialis, and Sorghum scoparium participated in the buffaloes' diet during summer, while Setaria verticillata and Sorghum halepense were consumed during autumn. The buffaloes' graminoid diet during winter consisted only of the five species that were constantly consumed as mentioned above.

From legumes, Trifolium repens was the dominant species in all seasons. Also, Melilotus neapolitanus and Vicia sp. were consumed by buffaloes but in minor proportions and not in all seasons.

A total of 22 forbs participated in the water buffaloes' diet during spring, 12 in summer, nine in autumn, and seven in winter. Cichorium intybus and Plantago lanceolata were consumed during all seasons, with the former being predominant. Apart from these plants, the relative contribution of Carlina vulgaris, Cerastium arvense, Erodium cicutarium, Plantago amplexicaulis, Plantago lanceolata and Ranunculus repens in the diet was greater than $1 \%$ in spring, whereas the remaining forbs were in lower percentages. Forbs were also included in the diet in small proportions $(<1 \%)$ during summer, except Cichorium intybus. In autumn, only Plantago major and Portulaca oleracea were consumed by buffaloes at percentages higher than $1 \%$, while during winter one species (Rumex pulcher) was above this level.

Similarly to the other plant functional groups, a greater variety of shrub species in the buffaloes' diet was observed during spring (six species) in contrast to summer (two), autumn (two), and winter (one). Rubus sp. was present in the buffaloes' diet in all seasons, ranging from $1.3 \%$ in autumn to $5.6 \%$ in spring. Apart from Rubus sp., Sambucus nigra was also included in the diet during autumn, although in greater amounts. In general, all the other shrubs were consumed in small proportions $(0.1 \%$ to $0.9 \%)$.

Trees were a negligible component of the buffaloes' diet. Six trees were recorded in spring, three in summer, three in autumn and one in winter. Populus sp. was the tree consumed in all seasons, followed by Salix alba, which participated in buffaloes diet with very low percentages $(<0.2 \%)$.

The Spearman's test revealed a strong correlation (rho $=0.947, P<0.001)$ between the seasonal proportion (\%) of each plant functional group in the wet grasslands' vegetation and their proportion (\%) to the water buffaloes' diet (Table 3). Also, Spearman's test detected a significant association between the proportion (\%) of plant species in the vegetation and their proportion (\%) in the water buffaloes' diet in each season (rho $=0.475$ for spring, rho $=0.840$ for summer, rho $=0.719$ for autumn, and rho $=0.616$ for winter; $P<0.01$ in all cases). 
Table 3: Correlation coefficient (Spearman's rho) and its significance level between the proportion (\%) of plant functional groups in the wet grasslands vegetation and their proportion (\%) to the buffaloes' diet across seasons.

Tabela 3: Korelacijski koeficienti (Spearman rho) in statistična značilnost med deleži rastlinskih vrst (\%) v funkcionalnih skupinah na mokrotnih travnikih in in njihovim deležem (\%) v prehrani bivolov v različnih sezonah.

\begin{tabular}{|c|c|c|c|c|c|}
\hline Season & $\begin{array}{l}\text { Plant Functional } \\
\text { group }\end{array}$ & $\begin{array}{l}\text { Proportion }(\%) \\
\text { in the vegetation }\end{array}$ & $\begin{array}{c}\text { Proportion }(\%) \\
\text { in the water buffaloes' diet }\end{array}$ & $\begin{array}{l}\text { Correlation } \\
\text { coefficient } \\
\end{array}$ & $\begin{array}{c}\text { Significance } \\
\text { level }\end{array}$ \\
\hline \multirow{3}{*}{ Spring } & Graminoids & 9.85 & 10.87 & \multirow{13}{*}{ rho $=0.947$} & \multirow{13}{*}{$P<0.001$} \\
\hline & Legumes & 6.39 & 6.11 & & \\
\hline & Forbs & 8.76 & 7.16 & & \\
\hline \multirow{3}{*}{ Summer } & Graminoids & 14.28 & 17.95 & & \\
\hline & Legumes & 8.14 & 6.34 & & \\
\hline & Forbs & 2.58 & 1.14 & & \\
\hline \multirow{3}{*}{ Autumn } & Graminoids & 15.19 & 19.92 & & \\
\hline & Legumes & 6.31 & 2.13 & & \\
\hline & Forbs & 3.50 & 2.87 & & \\
\hline \multirow{3}{*}{ Winter } & Graminoids & 11.31 & 17.38 & & \\
\hline & Legumes & 5.86 & 3.20 & & \\
\hline & Forbs & 7.83 & 4.93 & & \\
\hline Total & & 100.0 & 100.0 & & \\
\hline
\end{tabular}

\section{Discussion}

Water buffaloes in our study were mainly grazers than browsers as graminoids, legumes, and forbs made up the fundamental part of their diet in all seasons. These findings are in accordance with Tsiobani et al. (2014) who reported that water buffaloes spent more time feeding on grasses $(74 \%)$ in comparison to woody species $(21.5 \%)$ and forbs (4.5\%). Napolitano et al. (2007) also highlighted the importance of herbaceous vegetation and reported the absence of woody species in the water buffaloes' diet. It seems that water buffaloes, like cattle, due to their anatomical characteristics (wide mouth and inflexible upper lips) are not well adapted to harvest woody vegetation (Phillips 1988).

Moreover, seasonal changes in the water buffaloes' dietary composition were revealed in our study. Specifically, during spring the contribution of graminoids to the water buffaloes' diet was decreased (44.5\%) in comparison to the other seasons. This could be mainly attributed to the low consumption of Cynodon dactylon, despite its high nutritive value (Ramirez et al. 2003), in favor of other graminoids, such as Alopecurus pratensis, Carex sp., Hordeum murinum, Phragmites australis, and Poa trivialis. The observed low contribution of graminoids to the water buffaloes' diet during this period was compensated by the increased consumption of highly nutritious legumes (22.1\%), forbs (25.7\%), and shrubs (6.6\%) (Ulyatt et al. 1988, Yiakoulaki et al. 2007). Trifolium repens was the dominant legume in their diet while Melilotus neapolitanus was consumed in very low proportions (0.7\%). Among the forbs, Cichorium intybus was the most favored species (8.2\%) followed by Plantago lanceolata (4\%). Both these species have high nutritive value and their abundance in the vegetation could enhance the nutritional profile of grasslands (Sanderson et al. 2003).

The consumption of Ranunculus repens (2.3\%), although its poisonous effects on livestock, may be justified by the fact that grazing animals are able either to tolerate toxic plants - if they are familiar in the grazing area, or metabolize them efficiently into their rumen or outcome their poisonous impact by consuming other herbs (Valentine 1990, Provenza et al. 1992). Rubus sp. and Populus sp. were the main woody species in the water buffaloes' diet in spring. According to our observations, the animals used to consume the outer foliage and thin twigs (2-3 cm diameter) of Rubus sp., which are soft and without thorns. It was observed that despite the numerous plant species that contributed to buffaloes diet during this period, a large proportion of them (69\%) were just tested by the animals, meaning that they were selected in very low percentages $(<1 \%)$. In this regard, Hejcman et al. (2008) stated that grazing sheep also tested a wide scale of plant species but in low selection frequency.

In the summer, the graminoids and legumes accounted for the vast majority $(92.0 \%)$ in the water buffaloes' diet. This can be attributed to the high participation of Cynodon dactylon (56.6\%) and Trifolium repens (23.9\%). These species with their numerous rhizomes and stolons (Mislevy 1979) are able to spread and persist in various envi- 
ronmental conditions (Harlan et al. 1970, Grime 1979, Evans 1973). They can also form associations between them competing thus with species of a smaller presence in the grassland (Bogdan 1977, Orr et al. 1990). Sorghum scoparium was also included in the diet in percentage of $2.7 \%$, despite its possible toxic effects on cattle (Vough 1978). Also, during this period $64 \%$ of the plant species that participated in buffaloes' diet were grazed in percentages lower than 1\%. Legumes, such as Melilotus neapolitanus and forbs, like Carlina vulgaris, Convolvulus arvensis, Fumaria officinalis, Mentha pulegium, Nigella damascena, Ranunculus sardous, Silybum marianum etc. seems to be undesirable to water buffaloes. This can be attributed either to their morphological structure (thorns) or the presence of toxic substances, such as alkaloids, saponins, cumarin, glycosides etc (Mardirossian et al. 1983, Todd et al. 1995, Al-Sultan et al. 2003). It appears that the water buffaloes tended to test the numerous available plant species on the wet grassland awaiting for a post-ingestive response (Provenza et al. 2003).

In autumn and winter, fewer species were found in the buffaloes' diet compared to the other seasons. During these periods, the same pattern was also followed as in spring and summer regarding the participation of plant species with percentages lower than $1 \%$.

In our study, a strong correlation was found between the abundance of species in the wet grassland's vegetation and those that were consumed by animals. These findings are consistent with Soder et al. (2009) who stated that grazing animals alter their diet not only due to their preference for certain species but also from the availability of these species in the grassland's vegetation. However, the proportion of plant species in animals' diet does not always coincide with their proportion in grasslands' composition (Galt et al. 1982, Hejcman et al. 2008). According to our results, 38 herbaceous species in total (four graminoids and 34 forbs) that were present in the wet grassland's vegetation did not appear in buffaloes' diet. This was more evident during winter when only $46 \%$ of the available herbaceous flora was grazed by buffaloes. This finding can be attributed either to the low availability of these plant species in the wet grasslands' vegetation or their low palatability. Particularly, forbs are markedly decreased and disintegrated in winter or remain as stemmy remnants, which make them undesirable for the animals (Valentine 1990).

\section{Conclusion}

Water buffaloes grazing on wet grasslands have to face several challenges in terms of consuming both herbaceous and woody species. Few species (10) from all plant functional groups were constantly consumed by buffaloes in all seasons while the greater number of plants constituting their diet was simply tested by them. In this study, the seasonal changes in water buffaloes' diet composition were revealed. However, it is important to understand the water buffaloes' foraging strategy in relation to anti-quality characteristics of plant species.

\section{Acknowledgments}

The research was funded by the Research Committee of the Aristotle University of Thessaloniki, Greece (Contract Number 92868). The authors wish to thank the professor emeritus Konstantinos Papanikolaou, for his help in the identification of the plant species, as well as Mr. John Moutas, for his valuable contribution in collecting the plant species during the study.

Eleni T. Tsiobani D, https://orcid.org/0000-0002-5142-6082
Maria D. Yiakoulaki (D, https://orcid.org/0000-0001-9827-6627
Georgios Menexes (D), https://orcid.org/0000-0002-1034-7345

\section{References}

Al-Sultan, S. I., Hussein, Y. A. \& Hegazy, A. 2003: Toxicity of Anagallis arvensis plant. Pakistan Journal of Nutrition 2(3): 116-122.

Altmann, J. 1974: Observational study of behaviour: sampling methods. Behaviour 49(3-4): 227-267.

Antkowiak, I., Pytlewski, J., Purczynska, A. \& Skrzypek, R. 2012: A preliminary study of the behaviour of water buffaloes (Bubalus bubalis) imported to Poland. Archiv Tierzucht 55(5): 415-419.

Blondel, J. 2003: Guilds or functional groups: does it matter? Oikos 100(2): 223-231.

Bogdan, A. V. 1977: Tropical pasture and fodder plants (graminoids and legumes). Longman: London and New York. p. 475.

Bonham, C. D. 2013: Measurements for terrestrial vegetation. WileyBlackwell. p. 254.

Cibils, A. F., Howery, L. D. \& Ruyle, G. B. 2004: Diet and habitat selection by cattle: the relationship between skin-and gut-defense systems. Applied Animal Behaviour Science 88(3-4): 187-208.

Duncan, P., Danell, K., Bergström, R. \& Pastor, J. 2006: Large herbivore ecology, ecosystem dynamics and conservation. Cambridge University Press. p. 523.

Evans, P. S. 1973: The effect of repeated defoliation to three different levels on root growth of five pasture species. New Zealand Journal of Agricultural Research 16: 31-34.

FAO 2007: Food and Agriculture Organization of the United Nations. Breeds currently recorded in the Global Databank for Animal Genetic Resources. Rome, Italy, pp. 155. 
Fraser, M. D., Theobald, V. J., Griffiths, J. B., Morris, S. M. \& Moorby, J. M. 2009: Comparative diet selection by cattle and sheep grazing two contrasting heathland communities. Agriculture, Ecosystems \& Environment 129(1-3): 182-192. https://doi. org/10.1016/j.agee.2008.08.013

Galt, H. D., Theurer, B., Clark Martin, S. 1982: Botanical Composition of Steer Diets on Mesquite and Mesquite-Free Desert Grassland. Journal of Range Management 35(3): 320-325. doi: $10.2307 / 3898310$

Georgoudis, A. G. 1993: Population characteristics and production systems of water buffaloes in Greek wetlands. Greek Biotope / Wetland Centre and Department of Animal Production, Faculty of Agriculture, Aristotle University of Thessaloniki. p. 64. (In Greek, English summary)

Ginane, C. \& Dumont, B. 2010: Do grazing sheep use speciesbased categorization to select their diet? Behavioural Processes 84(2): 622-624.

Ginane, C., Bonnet, M., Baumont, R. \& Revell, D. K. 2015: Feeding behaviour in ruminants: a consequence of interactions between a reward system and the regulation of metabolic homeostasis. Animal Production Science 55(3): 247-260.

Grime, J. P. 1979: Plant strategies and vegetation processes. John Wiley $\&$ Sons, New York. p. 222

Harlan, J. R., de Wet, J. M. J., Huffine, W. W. \& Deakin, J. R. 1970 A guide to the species of Cynodon (Gramineae). Bulletin of the Agricultural Experiment Station Oklahoma State University B 673: p. 37

Hejcman, M., Žáková, I., Bílek, M., Bendová, P., Hejcmanová, P., Pavlů, V. \& Stránská, M. 2008: Sward structure and diet selection after sheep introduction on abandoned grassland in the Giant Mts, Czech Republic. Biologia 63(4): 506-514. doi: 10.2478/s11756-008-0076-1

Jerrentrup, J. S., Seither, M., Petersen, U. \& Isselstein, J. 2015: Little grazer species effect on the vegetation in a rotational grazing system. Agriculture, Ecosystems \& Environment 202: 243-250. doi: http:// dx.doi.org/10.1016/j.agee.2015.01.007

Kazoglou, J. E. 2007: Effects of water buffalo grazing on wet meadows of Prespa National Park. PhD Thesis. Aristotle University of Thessaloniki, School of Forestry and National Environment. Thessaloniki. p. 254.

Keddy, P. A. 2010: Wetland ecology: principles and conservation (2nd Edition). Cambridge University Press, Cambridge, UK, p. 548.

Launchbaugh, K. L., Daines, R. J. \& Walker, J. W. (Eds.) 2006: Targeted grazing: a natural approach to vegetation management and landscape enhancement. Centennial, CO, USA: American Sheep Industry Association. p. 199

Mardirossian, Z. H., Kiryakovt, H. G., Ruder, J. P. \& MacLean, D. B. 1983: Alkaloids of Fumaria officinalis. Phytochemistry 22(3): 759-761.

Mislevy, P. 1979: Encroachments of common Bermuda grass (Cynodon dactylon L.) in subtropical and tropical perennial graminoids. In: Proceedings of the $36^{\text {th }}$ Southern Pasture and Forage Crop Improvement Conference, Beltsville, MD: pp. 119-120.

Mládek, J., Mládková, P., Hejcmanová, P., Dvorský, M., Pavlu, V., De Bello, F., Duchoslav, M. Hejcman, M. \& Pakeman, R. J. 2013: Plant trait assembly affects superiority of grazer's foraging strategies in species-rich grasslands. PLoS ONE 8: e69800. doi: 10.1371/journal. pone. 0069800
Moen, J., Andersen, R. \& Illius, A. 2006: Living in a seasonal environment. In: Duncan, P., Danell, K., Bergstrom, R. \& Pastor, J. (eds): Large herbivore ecology ecosystem dynamics and conservation. Cambridge University Press, Cambridge, pp. 50-70.

Napolitano, F., Grasso, F., Saltamacchia, F., Martiniello, P., Bilancione, A., Pacelli, C. \& De Rosa, G. 2007: Grazing behaviour of buffalo heifers. Italian Journal of Animal Science 6 (Suppl.2): 1256-1259.

Napolitano, F., Pacelli, C., Grasso, F., Braghieri, A. \& De Rosa, G. 2013: The behaviour and welfare of buffaloes (Bubalus bubalis) in modern dairy enterprises. Animal 7(10): 1704-1713. doi:10.1017/ S1751731113001109

Orr, R. J., Parsons, A. J., Penning, P. D. \& Treacher, T. T. 1990: Sward composition, animal performance and the potential production of grass/white clover swards continuously stocked with sheep. Grass and Forage Science 45(3): 325-336.

Owen-Smith, N. \& Novellie, P. 1982: What should a clever ungulate eat? American Naturalist 119(2):151-178.

Papanastasis, B. \& Ispikoudis, B. 2012: Rangeland ecology, 1st Edition, Giahoudis Press, Thessaloniki, Greece, p. 325. (In Greek).

Papastergiadou, E. \& Balabonas, D. 1992: Ecological studies on aquatic macrophytes of a dam Lake Kerkini Greece. Archiv für Hydrobiologie Supplement 90(2): 187-206.

Phillips, C. 1988: Cattle behaviour and welfare. Second Edition. Blackwell Science. p. 274.

Provenza, F. D., Pfister, J. A. \& Cheney, C. D. 1992: Mechanisms of learning in diet selection with reference to phytotoxicosis in herbivores. Journal of Range Management 45(1): 36-45.

Provenza, F. D., Villalba, J. J., Dziba, L. E., Atwood, S. B. \& Banner, R. E. 2003: Linking herbivore experience, varied diets and plant biochemical diversity. Small Ruminant Research 49(3): 257-274.

Psilovikos, A. \& Margoni, S. 2010: An empirical model of sediment deposition processes in Lake Kerkini, Central Macedonia Greece. Environmental Monitoring and Assessment 164(1-4): 573-592.

Ramirez, R. G., Gonzalez-Rodriguez, H. \& Garcia-Dessommes, G. 2003: Nutrient digestion of common bermudagrass (Cynodon dactylon L.) pers growing in Northeastern Mexico. Journal of Applied Animal Research 23(1): 93-102.

Sanderson, A. M., Labreveux, M., Hall, H. M. \& Elwinger, F. G. 2003: Nutritive value of chicory and English plantain forage. Crop Science 43: 1797-1804.

Soder, K. J., Gregorini, P., Scaglia, G. \& Rook, A. J. 2009: Dietary selection by domestic grazing ruminants in temperate pastures: current state of knowledge, methodologies, and future direction. Rangeland and Ecololgy Management 62(5): 389-398.

Strid, A. 1986: Mountain Flora of Greece. Vol.1. Cambridge University Press. p. 819.

Strid, A. \& Tan, K. 1991: Mountain Flora of Greece. Vol. 2. Edinburgh University Press. p. 974.

Todd, F. G., Stermitz, F. R., Schultheis, P., Knight, A .P. \& TraubDargatz, J. 1995: Tropane alkaloids and toxicity of Convolvulus arvensis. Phytochemistry 39(2): 301-303. 
Tóth, E., Deák, B., Valkó, O., Kelemen, A., Miglécz, T., Tóthmérész, B. \& Török, P. 2018: Livestock type is more crucial than grazing intensity: Traditional cattle and sheep grazing in short-grass steppes. Land Degradation \& Development 29(2): 231-239.

Tsiobani, E. T., Yiakoulaki, M. D., Hasanagas, N. D. \& Papanikolaou, K. Ch. 2014: Water buffaloes' diet selection grazing at the area of the Lake Kerkini, Northern Greece. Journal of Mountain Agriculture on the Balkans 17(1): 30-40.

Tsiobani, E. T., Yiakoulaki, M. D., Hasanagas, N. D., Menexes, G. \& Papanikolaou, K. 2016: Water buffaloes grazing behaviour at the Lake Kerkini National Park, Northern Greece. Hacquetia 15(2): 133-142. doi: 10.1515/hacq-2016-0015

Tutin, T. G., Heywood, V. H., Burges, N. A., Moore, D. M., Valentine, D. H., Walters, S. M. \& Webb, D. A. (Eds.): 1964-1980. Flora Europaea, Cambridge University Press, Vol. 1-5.

Ulyatt, M. J., Thomson, D. J., Beever, D. E., Evans, R. T. \& Haines, M. J. 1988: The digestion of perennial ryegrass (Lolium perenne $\mathrm{cv}$. Melle) and white clover (Trifolium repens $\mathrm{cv}$. Blanca) by grazing cattle. British Journal of Nutrition 60(1): 137-149.

Valentine, J. 1990: Grazing management. Academic Press, $2^{\text {nd }}$ Edition. p. 533 .

van der Valk, A. 2006: The Biology of Freshwater Wetlands. Biology of Habitats.Oxford University Press, p.186.
Verhoeven, J. T. A., Beltman, B., Whigham, D. F. \& Bobbink, R 2006: Wetland functioning in a changing world: Implications for natural resources Managements. In: Verhoeven, J. T. A., Beltman, B., Bobbink, R. \& Whigham, D. F. (Eds.). Wetlands and natural resource management. Ecological Studies, Vol 190, Analysis and Synthesis, Springer Books, pp. 1-12.

Villalba, J. J. \& Provenza, F. D. 2009: Learning and Dietary Choice in Herbivores. Rangeland Ecology \& Management 62(5): 399-406.

Vough, L. 1978: Preventing Prussic Acid Poisoning of Livestock. Extension Circular 950. Oregon State University Extension Service (retrieved from https://forages.oregonstate.edu/)

Weather Station of Chrysochorafa, 2018: http://xrysoxorafa. meteoclub.gr/

Whitmore, J. S. 2000: Drought management on farmland. Kluwer Academic Publishers. Netherlands. p. 293.

Yiakoulaki, M. D., Pantazopoulos, Ch. I. \& Papanastasis, V. P. 2007: Nutritive value of diet selected by sheep and goats grazing on woody rangelands in Northern Greece. In: Journal of Mountain Agriculture on the Balkans. Proceedings of $14^{\text {th }}$ FAO -CIHEAM Mountain Pastures Network pp. 172-180.

Zweifel-Schielly, B., Leuenberger, Y., Kreuzer, M. \& Suter, W. 2012: A herbivore's food landscape: seasonal dynamics and nutritional implications of diet selection by a red deer population in contrasting Alpine habitats. Journal of Zoology 286(1): 68-80. 